\title{
NPK-lannoituksen vaikutus Pito-perunan satotekijöihin
}

\author{
EERO VARIS \\ Hankkijan kasvinjalostuslaitos, Anttilan koetila, Hyrylä
}

Saapunut 30.5.1973

\section{The effects of increased $\mathrm{N}, \mathrm{P}$, and $\mathrm{K}$ rates on yield factors of Pito potato}

Eero VARIS

The Hankkija Plant Breeding Institute, 04300 Hyrylä

\begin{abstract}
The purpose of this study was to examine by growth analysis how increased rates of $\mathrm{N}, \mathrm{P}$, and $\mathrm{K}$ affect the morphological characteristics of the potato plant and whether the yield differences found could be accounted for these factors.

$\mathrm{N}$ applications caused a heavy increase in the vegetative growth of the haulms, but tuber yield increased only up to the $\mathrm{N}_{1}$ rate, $100 \mathrm{~kg} \mathrm{~N} / \mathrm{ha}$. Root weight behaved similarly to haulm weight. $\mathrm{N}$ applications delayed the development of the tuber yield and increased the number of stems and tubers. The relative proportions of large and small tubers were partly affected by $\mathrm{N}$ application.

$\mathrm{P}$ applications increased the vegetative growth of haulms and the tuber yield up to the highest amount used, $168 \mathrm{~kg} \mathrm{P} / \mathrm{ha}$. $\mathrm{P}$ increased the number of tubers and accelerated development of the yield.

$\mathrm{K}$ applications did not affect the yield. They only increased slightly the number of stems.

$\mathrm{N}$ and $\mathrm{P}$ interacted in many respects. In most cases the most favourable result was achieved with a certain $\mathrm{N}$ : $\mathrm{P}$ ratio, corresponding to the $\mathrm{N}_{1} \mathrm{P}_{1}$ or $\mathrm{N}_{2} \mathrm{P}_{2}$ in this study.
\end{abstract}

Tämä koesarja on jatkoa lannoitustutkimukselle vuosilta 1965-67, jossa selvitettiin NPK-lannoituksen vaikutusta Pito-perunan satoon ja laatuun eri puolilla maata (VARIs 1972 a, b). Tässä tutkimuksessa pyrittiin tarkemmin selvittämään käytettyjen pääravinteiden vaikutustapaa Pito-perunan morfologisiin, satoa määrääviin ominaisuuksiin selitykseksi aikaisemmissa tutkimuksissa-todetuille satoeroille.

Koeaineisto ja sen käsittely

Kokeet järjestettiin vuosina 1967, 1968 ja 1970 Hankkijan kasvinjalostuslaitoksen Anttilan koetilalla. Koelajike oli Pito ja koejäsenet samat kuin mainitussa laajemmassa tutkimuksessa: 


$$
\begin{aligned}
& \mathrm{N}_{0}=0 \\
& \mathrm{~N}_{1}=100 \mathrm{~kg} / \mathrm{ha} \mathrm{N}(400 \mathrm{~kg} / \mathrm{haNos}) \\
& \mathrm{N}_{2}=200 \mathrm{~kg} / \mathrm{ha}(800 \mathrm{~kg} / \mathrm{ha} \mathrm{Nos}) \\
& \mathrm{P}_{0}=0 \\
& \mathrm{P}_{1}=87 \mathrm{~kg} / \mathrm{ha} \mathrm{P}(1000 \mathrm{~kg} / \mathrm{haPsf}) \\
& \mathrm{P}_{2}=174 \mathrm{~kg} / \mathrm{ha} \mathrm{P}(2000 \mathrm{~kg} / \mathrm{haPsf}) \\
& \mathrm{K}_{0}=0 \\
& \mathrm{~K}_{1}=166 \mathrm{~kg} / \mathrm{ha} \mathrm{K}(400 \mathrm{~kg} / \mathrm{ha} \mathrm{Ksu}) \\
& \mathrm{K}_{2}=332 \mathrm{~kg} / \mathrm{ha} \mathrm{K}(400 \mathrm{~kg} / \mathrm{ha} \mathrm{Ksu})
\end{aligned}
$$

\begin{tabular}{|c|c|c|c|c|c|}
\hline Vuosi & $\mathrm{pH}$ & $\mathrm{P}$ & K & $\mathrm{Ca}$ & $\mathrm{Mg}$ \\
\hline $1967 \ldots \ldots+\cdots \cdots$ & 5.1 & 6 & 144 & 869 & 200 \\
\hline 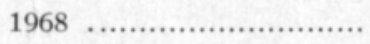 & 5.4 & 6 & 137 & 869 & 181 \\
\hline 1970 & 55 & $=$ & & & 312 \\
\hline
\end{tabular}

Koealue oli kaikkina vuosina sama aitosavipohjainen multamaalohko. Koealueen maa-analyysiarvot olivat seuraavat:

Lannoitteet kylvettiin ennen istutusta avattuihin vakoihin. Ruudut olivat 4-rivisiä, $7.5 \mathrm{~m}$ pitkiä (à 25 mukulaa), ja niistä korjattiin yksi rivi käsin joka nostossa. Kerranteita oli 2.

Nostoajat (keskimäärin):
23.07.
08.08 .
27.08.
13.09.

Tutkitut ominaisuudet:

1. Mukulasato. Ruutusadot punnittiin ja tulokset laskettiin g/yksilö. Vastaaviin hehtaarisatoihin päästään kertomalla yksilösadot 50.000:lla.

2. Varsisato. Varret katkaistiin sirpillä maan pinnan tasalta ja punnittiin ruuduittain. Tulokset laskettiin kuten edellä g/yksilö.

3. Juurisato. Varovaisessa käsinnostossa mukaan tullut juurimassa ja rönsyt punnittiin ja tulokset laskettiin kuten edellä $\mathrm{g} / \mathrm{yksilö.}$

4. Versojen määrä. Ennen nostoa laskettiin pääversojen määrät ruuduittain ja tulokset laskettiin kuten edellä $\mathrm{kpl} / \mathrm{yksilö.}$

5. Mukuloiden määrä. Ruutusadoista laskettiin mukuloiden määrä. Tulokset esitetään kpl/ yksilö.

6. Mukuloiden kokojakautuma. Sato lajiteltiin 40 ja $55 \mathrm{~mm}$ seuloilla. Tuloksissa käsitellään isojen (yli $55 \mathrm{~mm}$ ) ja pienten (alle $40 \mathrm{~mm}$ ) mukuloiden sadon osuutta \%:ina koko sadosta.

Tulosten tilastollisessa käsittelyssä käytettiin varianssianalyysejä, jotka laskettiin Keskusosuusliike Hankkijan ATK-osastolla. Tulosten tilastollinen merkitsevyys on ilmaistu seuraavasti:

$$
\begin{aligned}
* * * & =99.9 \%: \text { n merkitsevyys } \\
* * & =99 \\
* & =95 \\
\left(^{*}\right) & =90 \\
\mathrm{~ns} & =\text { ei merkitsevä }
\end{aligned}
$$


Varianssianalyysin tulokset on esitetty Taulukossa 1. Kuten tavallista, kaikki tutkitut ominaisuudet vaihtelivat vuosittain (A). Samoin myös päävaikutus "nostoaika" (B) oli kaikkien ominaisuuksien osalta merkitsevä, kuten myös yhdysvaikutus $\mathrm{AB}$. Tuloksissa käsitellään ainoastaan N-, P- ja K-vaikutuksia sekä näihin liittyviä yhdysvaikutuksia.

Taulukko 1. Varianssianalyysi NPK-lannoituksen vaikutuksesta Pito-perunan sadonmuodostukseen $(\mathrm{N}=648)$

Table 1. Analysis of variance of the effects of increasing $N, P$, and $K$ rates on yield factors of the Pito-potato $(N=648)$

\begin{tabular}{|c|c|c|c|c|c|c|c|}
\hline $\begin{array}{l}\text { Tekijä } \\
\text { Factor }\end{array}$ & $\begin{array}{c}\text { Mukulasa- } \\
\text { to g/yks. } \\
\text { Tuber } \\
\text { yield } \\
\text { g per hill }\end{array}$ & $\begin{array}{l}\text { Varsisato } \\
\text { g/yks. } \\
\text { Haulm } \\
\text { yield } \\
\text { g per hill }\end{array}$ & $\begin{array}{l}\text { Juurisato } \\
\text { g/yks. } \\
\text { Root yield } \\
\text { g per hill }\end{array}$ & $\begin{array}{c}\text { Versoja } \\
\text { kpl/yks. } \\
\text { Stem } \\
\text { number } \\
\text { per hill }\end{array}$ & $\begin{array}{c}\text { Mukuloita } \\
\text { kpl/yks. } \\
\text { Tuber } \\
\text { number } \\
\text { per hill }\end{array}$ & $\begin{array}{l}\text { Yli } 55 \mathrm{~mm} \\
\text { mukuloita } \\
\text { Over } 55 \mathrm{~mm} \\
\text { tubers } \%\end{array}$ & $\begin{array}{c}\text { Alle } 40 \mathrm{~mm} \\
\text { mukuloita } \\
\text { Under } \\
40 \mathrm{~mm} \\
\text { tubers } \%\end{array}$ \\
\hline
\end{tabular}

\begin{tabular}{|c|c|c|c|c|c|c|c|c|}
\hline \multicolumn{2}{|c|}{ A Vuosi - Year } & $* * *$ & $* * *$ & $* * *$ & $* * *$ & $* * *$ & $* * *$ & $* * *$ \\
\hline \multicolumn{2}{|c|}{$\begin{array}{r}\text { B Nostoaika .... } \\
\text { Time of harvest }\end{array}$} & $* * *$ & $* * *$ & $* * *$ & $* * *$ & $* * *$ & $* * *$ & $* * *$ \\
\hline \multicolumn{2}{|c|}{$\mathrm{N} \quad \ldots \ldots \ldots \ldots \ldots \ldots$} & $* * *$ & $* * *$ & $* * *$ & $* * *$ & $* * *$ & ns & $* * *$ \\
\hline \multicolumn{2}{|c|}{$\mathrm{P}$} & $* * *$ & $* * *$ & ns & ns & $* * *$ & ns & ns \\
\hline \multicolumn{2}{|c|}{$\mathrm{K}, \ldots \ldots \ldots \ldots \ldots \ldots$} & ns & ns & ns & $(*)$ & ns & ns & $\mathrm{ns}$ \\
\hline \multicolumn{2}{|l|}{$\mathrm{AB} \ldots$} & $* * *$ & $* * *$ & $* * *$ & $* * *$ & $* * *$ & $* * *$ & $* * *$ \\
\hline \multicolumn{2}{|c|}{ AN $\ldots \ldots \ldots \ldots \ldots$} & $* * *$ & $* * *$ & ns & ns & $* * *$ & $* * *$ & $* * *$ \\
\hline \multicolumn{2}{|c|}{ AP $\ldots \ldots \ldots \ldots \ldots$} & $*$ & $* *$ & ns & ns & ns & $*$ & ns \\
\hline \multicolumn{2}{|c|}{$\mathrm{AK}, \ldots .}$. & ns & ns & ns & ns & ns & ns & ns \\
\hline \multicolumn{2}{|c|}{ BN ... } & $* *$ & $* * *$ & $*$ & ns & $*$ & ns & $*$ \\
\hline \multicolumn{2}{|c|}{ BP ... } & ns & ns & ns & ns & ns & ns & $*$ \\
\hline \multicolumn{2}{|c|}{ BK ...... } & ns & ns & $(*)$ & ns & ns & ns & ns \\
\hline \multicolumn{2}{|c|}{ NP ... } & $* *$ & $* * *$ & ns & ns & ns & $(*)$ & $(*)$ \\
\hline \multicolumn{2}{|c|}{ NK ................ } & ns & ns & ns & ns & ns & ns & ns \\
\hline \multicolumn{2}{|c|}{ PK ................. } & ns & ns & ns & ns & ns & ns & ns \\
\hline \multicolumn{2}{|c|}{ ABN $\quad \ldots \ldots \ldots \ldots$} & $(*)$ & $* *$ & $* *$ & ns & ns & $* *$ & $* * *$ \\
\hline \multirow{2}{*}{$\begin{array}{l}\text { ABP } \\
\text { ABK }\end{array}$} & ....... & ns & $*$ & $* *$ & ns & ns & ns & $(*)$ \\
\hline & …........... & ns & ns & ns & ns & ns & ns & ns \\
\hline \multirow{2}{*}{$\begin{array}{l}\text { ANP } \\
\text { ANK }\end{array}$} & ...... & ns & $* *$ & ns & $*$ & $(*)$ & ns & $*$ \\
\hline & ......... & ns & ns & ns & ns & ns & ns & ns \\
\hline APK & (.............. & ns & ns & ns & ns & ns & ns & ns \\
\hline BNP & ...... & ns & ns & ns & ns & ns & ns & ns \\
\hline BNK & .......... & ns & ns & $* *$ & ns & ns & ns & ns \\
\hline BPK & …........... & ns & ns & ns & ns & ns & ns & ns \\
\hline NPK & ….......... & ns & ns & ns & $\left({ }^{*}\right)$ & ns & ns & ns \\
\hline
\end{tabular}


N- ja P-lannoitus lisäsivät keskimääräistä mukulasatoa, tosin vuosittain eri tavalla (yhdysvaikutukset AN, AP). Kalilannoitus ei sen sijaan vaikuttanut satoon (Taulukko 1 ja Piirros 1). Piirroksessa esitetyt sadot edustavat lopullisia syyssatoja.

\section{Tuoresato g/kasvi \\ Green matter g/hill}

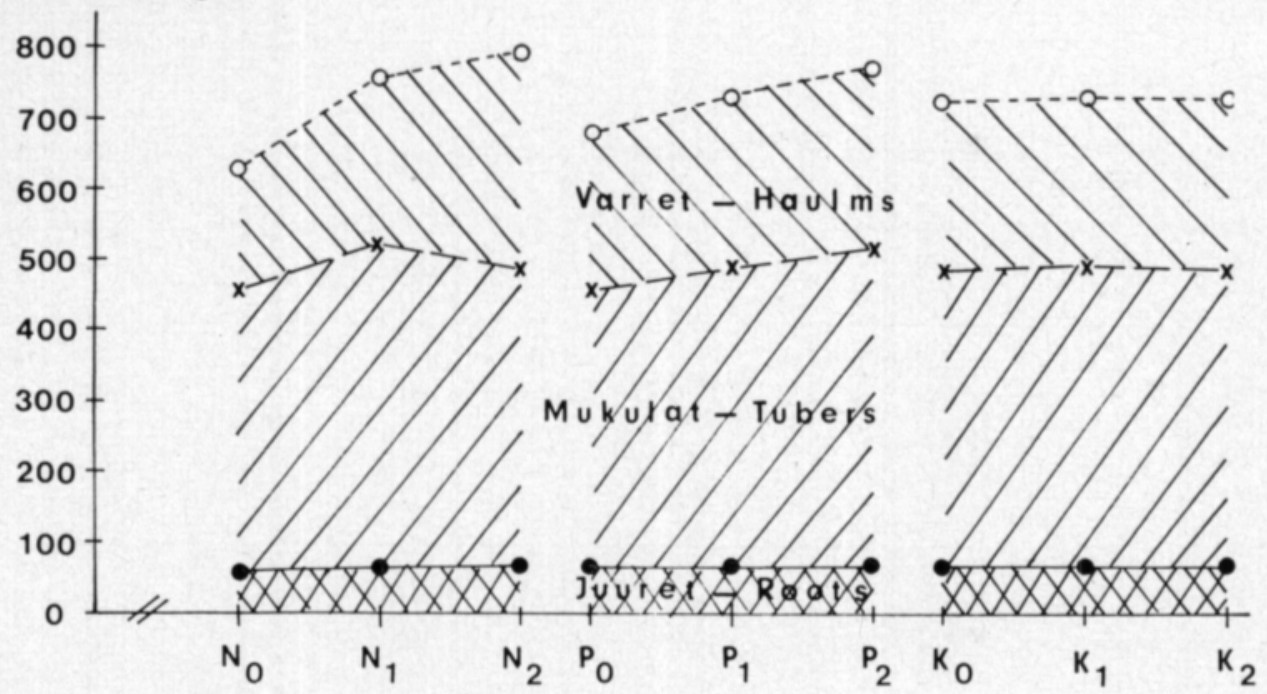

Piirros 1. N-, P- ja K-lannoituksen vaikutus Pito-perunan satoon.

Figure 1. The effect of increasing $N, P$, and $K$ rates on the yield of Pito potato.

Ravinteiden vaikutus mukulasatoon oli hyvin samanlainen kuin aikaisemmassa laajemmassa tutkimuksessa (VARIs 1972 a).

Sadonmuodostuksen rytmi oli samanlainen muilla paitsi N-koejäsenillä (yhdysvaikutus BN, Piirros 2).

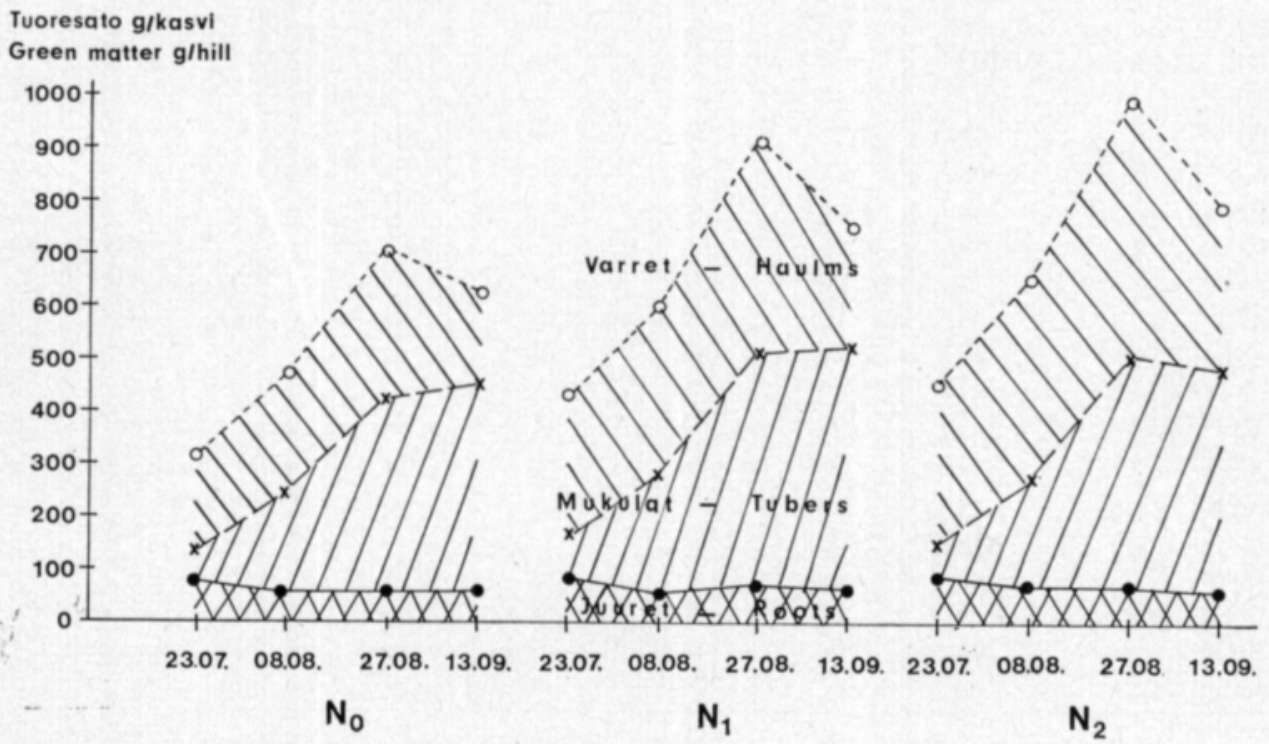

Piirros 2. Typpilannoituksen vaikutus Pito-perunan sadon kehittymiseen.

Figure 2. The effect of increasing $N$ rates on the development of the yield of Pito potato. 
Piirroksesta 2 käy selville, että typpilannoituksen satoa lisäävä vaikutus suureni kasvukauden loppua kohti ja $\mathrm{N}_{2}$-koejäsenellä nopeammin kuin muilla, kuten on todettu eräissä muissakin tutkimuksissa (CARLSSoN 1964). Ilmiö oli selvä varsinkin v. $1968(\mathrm{ABN})$.

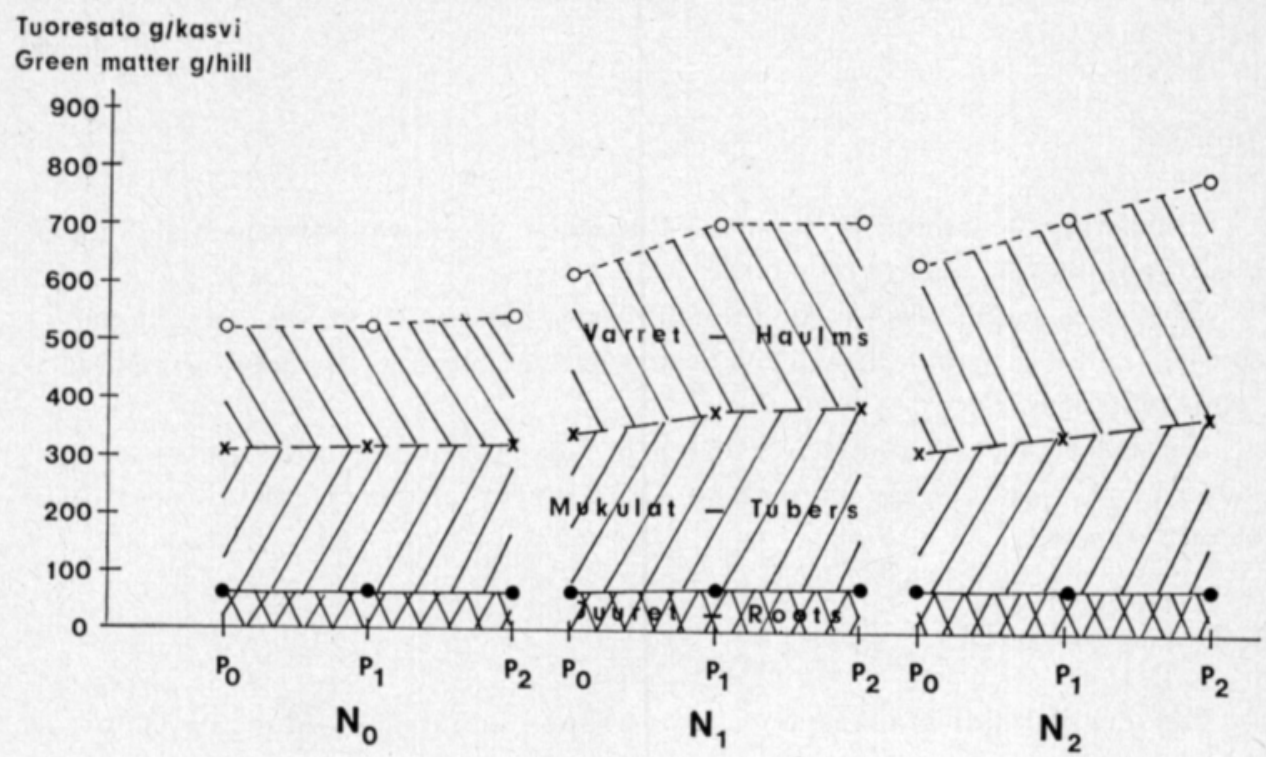

Piirros 3. Typen ja fosforin yhdysvaikutus Pito-perunan satoon.

Figure 3. The interaction of $N$ and $P$ as affecting the yield of Pito potato.

Typellä ja fosforilla oli yhdysvaikutus (NP, Piirros 3). Paras sato saavutettiin jo $\mathrm{N}_{1} \mathrm{P}_{1}$-tasolla. Sen jälkeen typen lisääminen alensi satoa, fosforin yksinään tai typen sekä fosforin lisääminen pitivät sen suunnilleen ennallaan (vrt. LOMAKKA 1966, VARIS 1972 a).

\section{Varsisato}

Typpi- ja fosforilannoitus lisäsivät myös varsisatoa (Taulukko 1). Typen vaikutus jatkui vielä $\mathrm{N}_{2}$-tasollakin (Piirros 1). Typen ja fosforin vaikutukset vaihtelivat vuosittain (AN, AP), vaikkakin suunta oli aina sama. Kalilannoitus ei vaikuttanut merkitsevästi varsisatoon. Samanlaisia tuloksia on typen osalta saanut mm. CARLsson (1964).

Typpilannoitus vaikutti varsiston kasvurytmiin (BN, Piirros 2). Tulokset muistuttavat niitä, joita CARLsson (1964) totesi typen osalta ja BENEPAL (1967) kaikkien ravinteiden osalta. $\mathrm{N}_{0}$ muistuttaa lisäksi aikaisen lajikkeen varsiston kehityskäyrää, $\mathrm{N}_{2}$ myöhäisen (vrt. CARLsson 1964). $\mathrm{N}_{1}$ ja $\mathrm{N}_{2}$-koejäsenien varsiston painon jyrkkä lasku syksyllä ei johtunut tuleentumisesta, vaan halloista, rutosta ym. häiriöistä, joita ei voitu koevuosina välttää.

Toisen asteen vaikutuksissa oli lisäksi vuotuista vaihtelua ( $\mathrm{BBN}, \mathrm{ABP}$ ).

Typellä ja fosforilla oli myös varsiston kasvun suhteen yhdysvaikutus (NP, Piirros 3). 
Yhdysvaikutus oli samantapainen kuin mukuloillakin todettu ja viittaa siihen, että sekä mukulasadon että varsiston kasvun kannalta sopiva NPsuhde johtaisi parhaaseen tulokseen. Mukuloiden kasvun kannalta optimaalinen NP-lannoituksen kokonaismäärä näytti olevan kuitenkin pienempi kuin varsien kasvun suhteen. Tässäkin yhdysvaikutuksessa oli kuitenkin vuotuista vaihtelua (ANP).

\section{Juuristo}

Ainoastaan N-lannoitus lisäsi merkitsevästi, tosin vähän, juurimassan painoa (Taulukko 1, Piirros 1).

Juuriston paino oli suurimmillaan ensimmäisessä nostossa. Typpilannoituksen juuriston painoa lisäävä vaikutus näkyi vain kasvukauden alkupuolella (yhdysvaikutus $\mathrm{BN}$ ).

Varsianssianalyysi osoitti edellisten lisäksi muutamia toisen asteen yhdysvaikutuksia, jotka eivät kuitenkaan merkinneet oleellista uutta todettuihin pieniin eroihin.

\section{Versojen lukumäärä}

Pääversojen (iduista kasvaneiden versojen) lukumäärä muuttui typpi- ja kalilannoituksen funktiona (Taulukot 1 ja 2 ).

Taulukko 2. N, P- ja K-lannoituksen vaikutus versojen ja mukuloiden lukumäärään Table 2. The effects of increased $N, P$, and $K$ rates on numbers of stems and tubers

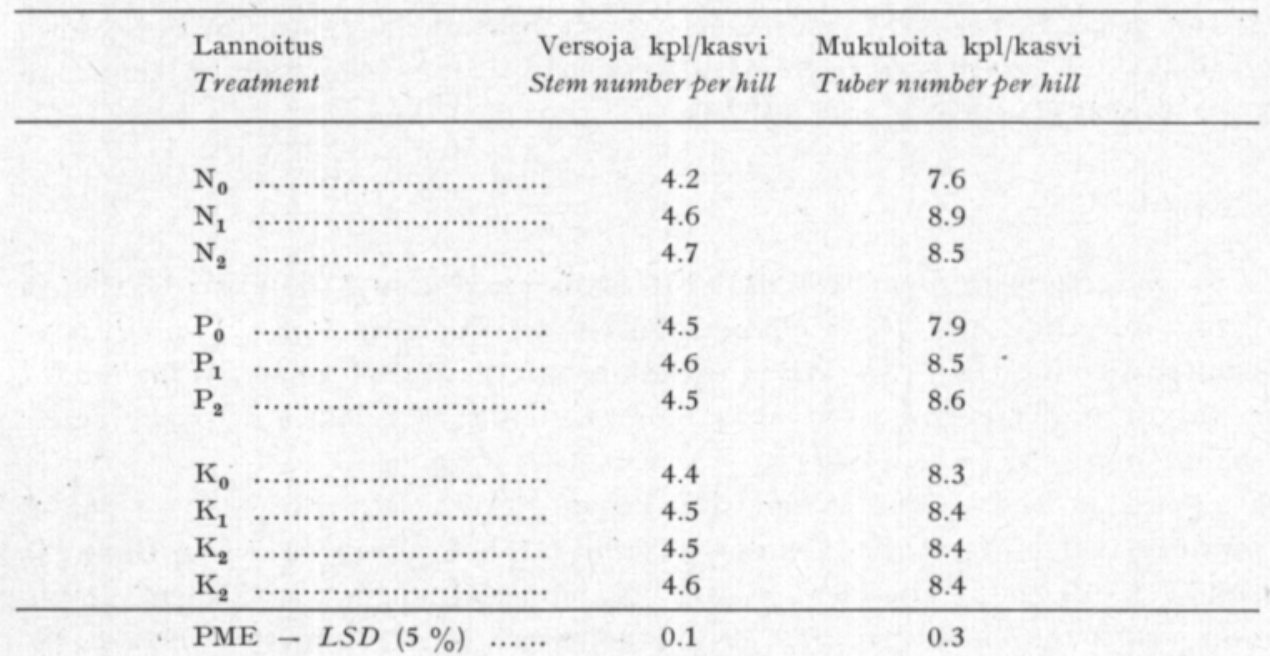

Typpilannoitus lisäsi selvästi versojen lukumäärää, samoin kalilannoitus lievästi. Typellä ja fosforilla oli jonain vuonna yhdysvaikutus (ANP), mikä oli samansuuntainen kuin varsien painossa todettu, nimittäin että versojen määrä lisääntyi eniten silloin, kun typpeä ja fosforia lisättiin samassa suhteessa $\left(\mathrm{N}_{1} \mathrm{P}_{1}, \mathrm{~N}_{2} \mathrm{P}_{2}\right)$. 


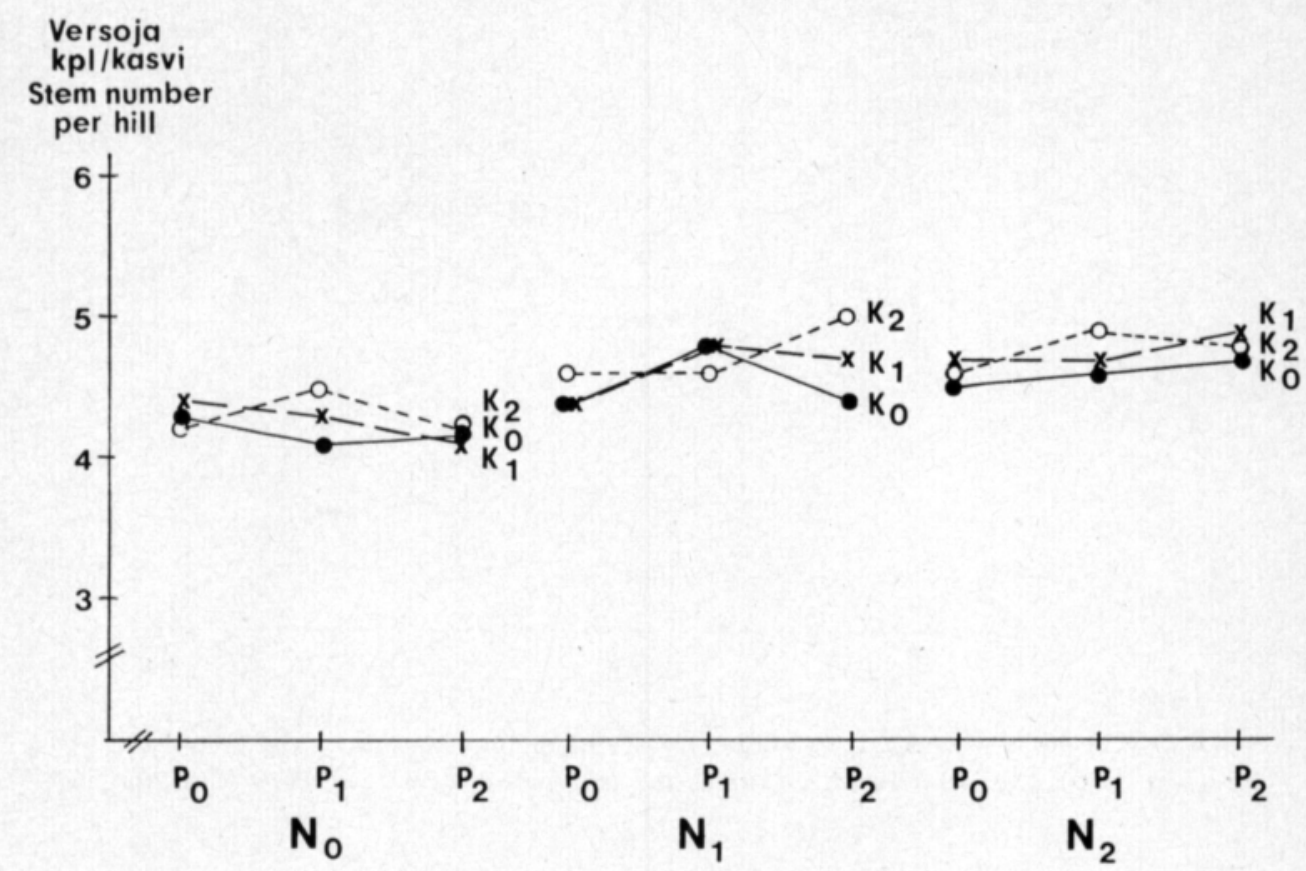

Piirros 4. NPK-lannoituksen yhdysvaikutus Pito-perunan versojen määrään.

Figure 4. The interaction of increased $N, P$, and $K$ rates as affecting the stem number of Pito potato.

Kaikilla ravinteilla oli lisäksi lievä yhdysvaikutus (Taulukko 1, piirros 4). $\mathrm{N}_{0}$-tasolla versojen lukumäärä oli suurin $\mathrm{P}_{1} \mathrm{~K}_{2}$-lannoituksella, $\mathrm{N}_{1}$-tasolla vastaavasti $\mathrm{P}_{2} \mathrm{~K}_{2}$-lannoituksella. $\mathrm{N}_{2}$-tasolla kalin ja fosforin vaikutukset eivät olleet niin selvät, paitsi että niiden puute $\left(\mathrm{K}_{0}, \mathrm{P}_{0}\right)$ alensi versojen lukumäärää. Näillä tuloksilla on tiettyjä yhtäläisyyksiä aikaisemmassa tutkimuksessa todettuihin mukulasatojen muutoksiin (VARIS 1972a).

Mukuloiden lukumäärä

Mukuloiden lukumäärä oli riippuvainen N- ja P-lannoituksesta (Taulukot 1 ja 2).

Kohtuullinen typpilannoitus $\left(\mathrm{N}_{1}\right)$ tai riittävä fosforilannoitus $\left(\mathrm{P}_{1}\right.$ ja $\left.\mathrm{P}_{2}\right)$ tuottivat suurimmat mukulamäärät. BENEPALin tutkimuksissa (1967) ei vastaavia muutoksia todettu.

Mukulamäärien vaihtelut kasvukauden kuluessa olivat riippuvaisia $\mathrm{N}$ lannoituksesta (Piirros 5). Runsas typpilannoitus $\left(\mathrm{N}_{2}\right)$ hidastutti kasvukauden alussa mukulanmuodostusta (vrt. CARLSSON 1964). Typellä ja fosforilla oli joinakin vuosina yhdysvaikutus (ANP), joka osoitti, että $\mathrm{N}_{0}$-tasolla runsas fosforimäärä alensi mukulalukua, kun se taas yhdessä typen kanssa lisäsi sitä (vrt. Piirros 4). 


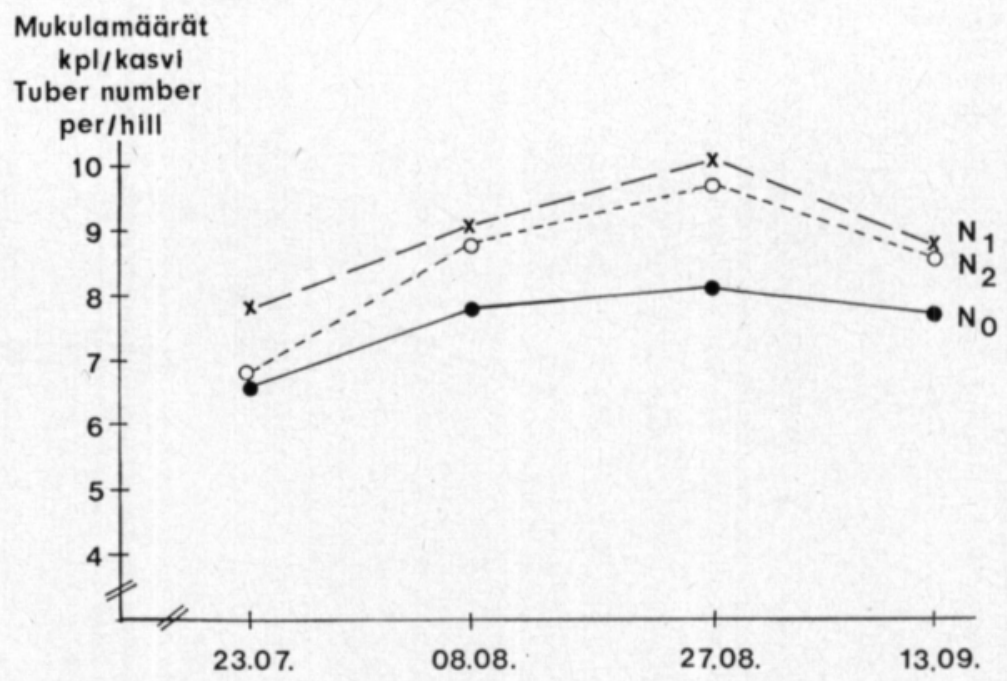

Piirros 5. Typpilannoituksen vaikutus Pito-perunan mukulamäärän kehittymiseen.

Figure 5. The effect of increased $N$ rates on the development of the tuber number of Pito potato.

\section{Mukuloiden kokojakautuma}

Kokojakautumassa tarkasteltiin isojen (yli $55 \mathrm{~mm}$ ) ja pienten (alle $40 \mathrm{~mm}$ ) mukuloiden osuutta koko sadosta.

Lannoitus ei tässä koesarjassa vaikuttanut merkitsevästi isojen mukuloiden osuuteen (Taulukot 1 ja 3), vaikka yleensä onkin niin todettu (CARLsson 1964, Enge 1970, Varis 1972 b). Herlihy ja Carrol (1969) totesivat typen lisäksi myös kalin suurentavan mukulakokoa.

Taulukko 3. NPK-lannoituksen vaikutus isojen ja pienten mukuloiden määriin (4 noston ka) Table 3. The effects of increased $N, P$, and $K$ rates on tuber size (av. of 4 liftings)

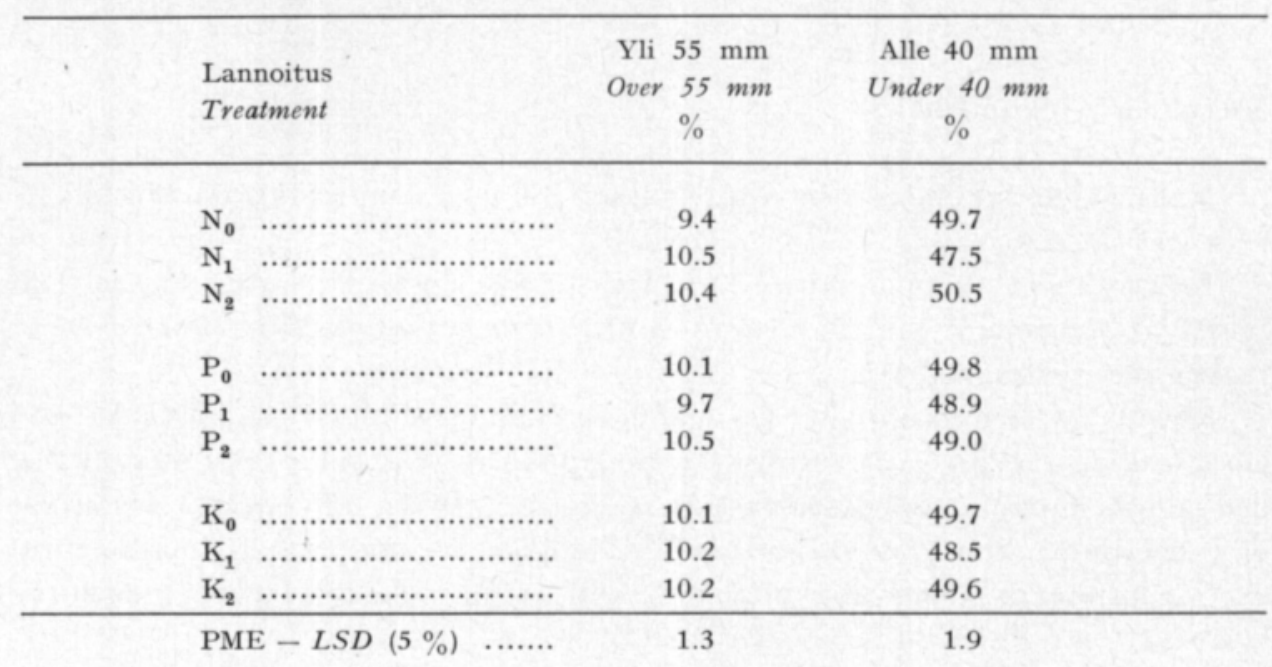


Typellä oli kuitenkin isojen mukuloiden määrää lisäävä trendi v. 1970. V. 1967 taas isojen mukuloiden osuus väheni typpilannoitusta lisättäessä (AN). Kasvukauden lopulla typpimäärä vaikutti vuosittain eri tavalla isojen mukuloiden määrään (ABN).

Fosforin vaikutus oli myös vuosittain erilainen (AP). V. 1967 fosforilannoitus lisäsi selvästi isojen mukuloiden osuutta, muina vuosina vaikutus oli vaihteleva.
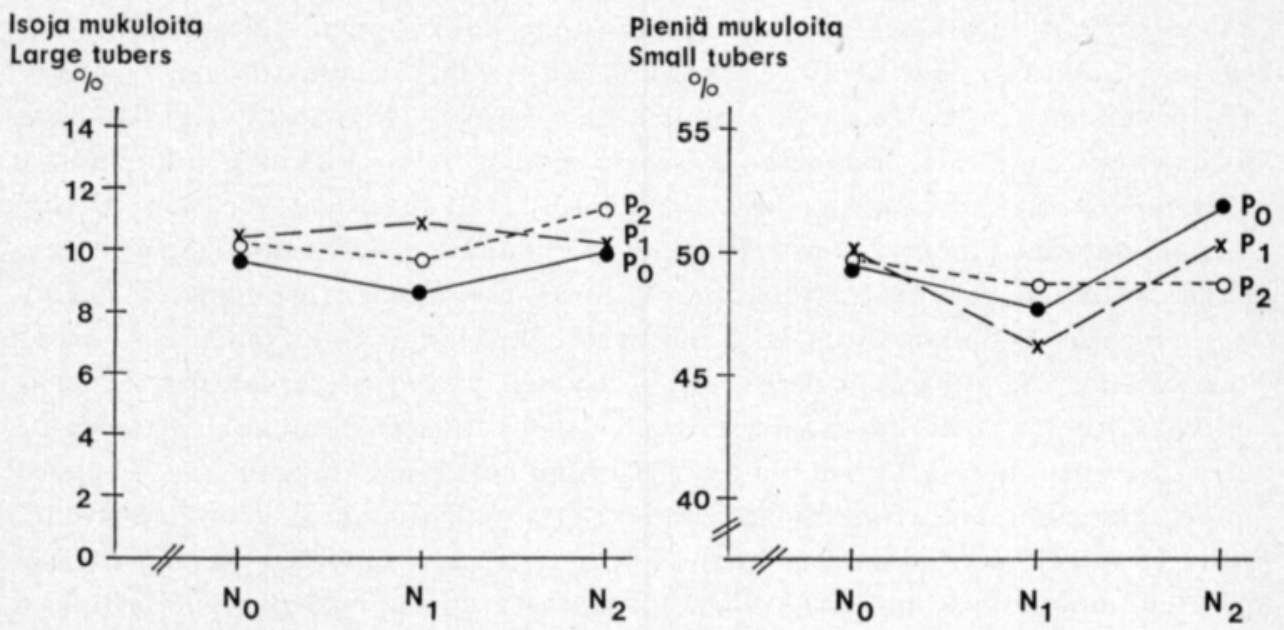

Piirros 6. Typpilannoituksen vaikutus Pito-perunan mukulakokoon.

Figure 6. The effect of increased $N$ rates on the tuber size of Pito potato.

Typellä ja fosforilla oli myös isojen mukuloiden määrään lievä yhdysvaikutus (NP, Piirros 6). $\mathrm{N}_{1}$-tasolla isojen mukuloiden määrä oli suurin fosforimäärän ollessa $\mathrm{P}_{1}, \mathrm{~N}_{2}$-tasolla vastaavasti suuri fosforimäärä $\left(\mathrm{P}_{2}\right)$ tuotti eniten suuria mukuloita (vrt. mukulasato).

Pienten mukuloiden osuus aleni $\mathrm{N}_{1}$-tasolla, mutta nousi taas $\mathrm{N}_{2}$-tasolla. Vuosittain tulos kuitenkin vaihteli (AN). Kasvukauden kuluessa pienten mukuloiden osuus vaihteli sekä typpi- että fosforilannoituksesta johtuen. Pienten mukuloiden osuus väheni nopeimmin $\mathrm{N}_{1^{-}}$sekä $\mathrm{P}_{1^{-}}$ja $\mathrm{P}_{2}$-lannoitusta käytettäessä. Syysnostossa eroja ei enää kuitenkaan ollut.

Typellä ja fosforilla oli lievä yhdysvaikutus myös pienten mukuloiden määrään (Taulukko 1 , Piirros 6). $\mathrm{N}_{1}$-tasolla pienten mukuloiden määrä oli pienin, kun fosforia oli kohtuullisesti $\left(\mathrm{P}_{1}\right) \cdot \mathrm{N}_{2}$-tasolla taas $\mathrm{P}_{2}$-määrä esti pienten mukuloiden määrän lisääntymisen.

\section{Tulosten tarkastelua}

Esitetyt tulokset osoittivat N- ja P-lannoituksen vaikuttavan Pito-perunan satoon jo aikaisemmin todetulla tavalla (VARIS 1972 a). Typpilannoitus lisäsi voimakkaasti koko kasvin kasvua, eniten varsiston kasvua (vrt. CARLsson 1964, Benepal 1967). Mukulasato ei sensijaan noussut samassa suhteessa, vaan se jopa alkoi laskea typpimäärän noustessa yli $100 \mathrm{~kg}: \mathrm{n} / \mathrm{ha}$. Fosforilan- 
noituksen satoa lisäävä vaikutus oli lievempi, mutta jatkuva, ja se suuntautui tasaisemmin varsiston ja mukuloiden osalle (vrt. BENEPAL 1967). Runsas typpilannoitus johti mukulasadon kehityksen viivästymiseen, mikä myöhäisellä Pito-lajikkeella todennäköisesti oli osatekijänä todettuun sadon alenemiseen (vrt. CARLsson 1964). Fosforilannoituksella ei selvää kasvurytmin morfologista muutosta todettu.

Typpi- ja fosforilannoitus vaikuttivat Pito-perunan muihinkin satotekijöihin varsiston ja juurien kasvun lisäksi. Kohtuullinen typpilannoitus lisäsi pääversojen lukumäärää ja sitä kautta myös mukuloiden lukumäärää. Sen sijaan liialliseksi katsottava typpilannoitus vähensi mukuloiden määrää. Fosforilannoituksella oli myös mukulalukua lisäävää vaikutusta. Kalilannoitus pystyi myös niukasti lisäämään versojen, mutta ei mukuloiden lukumäärää. Mukuloiden kokojakautuma myös muuttui, vaikkakin suhteellisen vähän. Typpilannoitus aiheutti, tosin tilastollisesti merkityksettömän, isojen mukuloiden osuuden kasvun, ja osittaisen pienten mukuloiden osuuden vähenemisen. Runsas typpilannoitus $\left(\mathrm{N}_{2}\right)$ hidastutti kuitenkin mukuloiden lisäkasvua syyskesällä. Typpilannoituksen satoa lisäävä vaikutus perustui siten sekä mukuloiden lukumäärän lisääntymiseen että osittaiseen mukulakoon suurenemiseen typen määrästä riippuen. Fosforilannoituksen vaikutus perustui samoin sekä mukulamäärän lisääntymiseen että niiden koon lievään muuttumiseen. Runsas fosforilannoitus näytti, päinvastoin kuin runsas typpi, vähentävän pienten mukuloiden määrää, mikä epäsuorasti viittaa mukulanmuodostuksen nopeampaan päättymiseen. Kalilannoituksen vaikutus oli näissäkin kokeissa peräti vähäinen. Englantilaisten tutkimusten mukaan kalilannoituksen mahdollinen satoa lisäävä vaikutus ilmenee pääasiassa suurten mukuloiden määrän lisääntymisenä (HerLIHY ja CARROLL 1969).

Selostettavassa tutkimuksessakaan todetut muutokset eivät kuitenkaan olleet säännöllisiä, sillä monet ulkoiset olosuhteet, kuten kasvukausien säät, vaikuttivat myös mukulanmuodostukseen ja kokojakautumaan. Voidaankin olettaa, että jos lannoituksen aiheuttama mukulanmuodostuksen lisääntyminen alkukesällä estyy jostain syystä, sen satoa lisäävä mahdollinen vaikutus ilmenee vaihtoehtoisesti pääasiassa mukulakoon suurenemisena.

BENEPALin (1967) tutkimuksissa ei todettu selviä mukulamäärien lisäyksiä, vaan hän on sitä mieltä, että typpi- ja fosforilannoituksen edullinen vaikutus perustuu pääasiassa lehdistön yhteyttämiskapasiteetin lisääntymiseen. Tämä tulos voi johtua amerikkalaisten lajikkeiden yleisestä ominaisuudesta olla muodostamatta lisämukuloita. Sadon suureneminen ilmeni hänen kokeissaan pääasiassa mukulakoon suurenemisena. SOMMERFELDT ja KNUTSON (1965) tulivat vuorostaan siihen tulokseen, että sekä runsas typpi- että fosforimäärä rajoittavat satoa vähentämällä mukulanmuodostusta. He totesivat myös runsaan fosforimäärän pienentävän mukulakokoa, minkä he otaksuvat johtuvan ennenaikaisesta tuleentumisesta. He totesivat myös runsaan typpilannoituksen pienentävän mukulakokoa.

Nämä tulokset antavat lisäviitteitä siitä, miten lannoitus vaikuttaa perunan kehitykseen ja sadon muodostumiseen. Tärkeitä tekijöitä näyttävät Suomen olosuhteissa olevan typpi ja fosfori. Näiden vaikutus on periaatteessa vastakkainen: typpi lisää huomattavasti varsiston kasvua, mutta samalla 
hidastuttaa mukulanmuodostusta. Perunan satopotentiaali tosin lisääntyy, mutta siitä hyötyminen riippuu lajikkeen aikaisuudesta ja kasvukauden pituudesta. Myös fosfori lisää perunan 'vegetatiivista kasvua ja siten myös satopotentiaalia. Samalla se kuitenkin nopeuttaa perunan kehitysrytmiä ja estää siten sadonmuodostuksen rytmin hidastumisen. Sekä yksipuolinen runsas typpilannoitus että myös yksipuolinen fosforilannoitus voivat johtaa sadon alenemiseen kumpikin näille ravinteille ominaisesta syystä. Näiden kahden vastakkaiseen suuntaan vaikuttavan tekijän välillä täytyy siten valita sopiva tasapaino. Tämä käy ilmi myös tässä tutkimuksessa yhdysvaikutuksista NP. NP-suhteen ei kuitenkaan tarvinne olla vakio, vaan se voinee vaihdella lajikkeen aikaisuuden ja olosuhteiden mukaan siten, että aikaiset lajikkeet sietävät typpivoittoisempaa NP-suhdetta kuin myöhäiset. Aikaistenkin lajikkeiden reagointi typpilannoitukseen on kuitenkin ENGEN (1970) mukaan siksi erilainen, että se on syytä lajikekohtaisesti ottaa huomioon. Hänen tutkimuksissaan jotkut lajikkeet reagoivat lannoitukseen pääasiassa mukulakoon kasvun muodossa, kun taas toiset lajikkeet herkemmin lisäsivät mukulalukuaan.

Näistä seikoista johtuen lannoituksen vaikutus perunan satotekijöihin voi olla joko mukulalukua tai mukulakokoa tai molempia lisäävä. Vaikutuksen tietoinen suuntaaminen jompaankumpaan tekijään vaatii tarkkaa lajikkeen ja kasvuolojen tuntemusta.

\section{Yhteenveto}

Tässä tutkimuksessa pyrittiin selvittämään NPK-lannoituksen vaikutustapaa Pito-perunan sadonmuodostukseen.

Typpilannoitus lisäsi voimakkaasti perunan varsiston kasvua, mutta mukulasatoa ainoastaan käytettyyn $\mathrm{N}_{1}$-määrään, $100 \mathrm{~kg} \mathrm{~N} /$ ha saakka. Myös juuriston paino kasvoi typpilannoitusta lisättäessä. Typpilannoitus hidasti mukulasadon kehitystä sekä lisäsi versojen ja mukuloiden lukumäärää. Sekä isojen että myös pienten mukuloiden osuudet muuttuivat osittain typpilannoitusta lisättäessä.

Fosforilannoitus lisäsi sekä varsiston painoa että mukulasatoa suurimpaan käytettyyn määrään, $168 \mathrm{~kg} \mathrm{P} / \mathrm{ha}$, saakka. Fosforilannoitus lisäsi mukuloiden lukumäärää sekä nopeutti mukuloiden lisäkasvua.

Kalilannoitus ei vaikuttanut satoon. Ainoastaan versojen määrä lisääntyi hiukan kalilannoitusta lisättäessä.

Typellä ja fosforilla todettiin yhdysvaikutus usean ominaisuuden suhteen. Useimmissa tapauksissa saatiin edullisin tulos sopivalla NP-suhteella, mikä tässä tutkimuksessa oli $\mathrm{N}_{1} \mathrm{P}_{1}$ tai $\mathrm{N}_{2} \mathrm{P}_{2}$. 


\section{KIRJALLISUUTTA}

Benepal, P. S. 1967. Correlations among applied nitrogen, phosphorus and potassium and responses of the potato plant. Amer. Potato J. 44: 75-86.

Bleasdale, J. K. A. \& Thomson, R. 1969. Some effects of plant spacing on potato quality. Eur. Potato J. 12: 173-187.

CARLsson, H. 1964. Utvecklingsförlopp och tillväxt hos potatis under vegetationsperioden. Lantbr.högsk. Medd. A 23:1-70.

ENGE, R. 1970. Virkningen av nitrogen, settepotetstorrelse og setteavstand på avlinga av tidligpoteter. Meld. Norg. Landbr.høgsk. 49,3:1-12.

Herlihy, M. \& Carroll, P. J. 1969. Effects of N, P, and K and their interactions on yield, tuber blight and quality of potatoes. J. Sci. Food Agric. 20:513-517.

LомаккА, L. 1966. Försök med gödsling av potatis i norra Sverige. Lantbr.högsk. Medd. A $44: 1-54$.

Sommerfeldt, T. G. \& KNUtson, K. W. 1965. Effects of nitrogen and phosphorus on the growth and development of Russet Burbank potatoes grown in Southwestern Idaho. Amer. Potato J. 42: 351-360.

VARIS, E. 1972 a. The effects of increasing NPK rates on the yield and quality of the Pito potato. I. Tuber yield, starch content and starch yield. Acta Agr. Fenn. 128, 1:1-20.

- $-1972 \mathrm{~b}$. The effects of increasing NPK rates on the yield and quality of the Pito potato. II. External and internal quality. Acta Agr. Fenn. 128, 2:1-23. 